\title{
Effect of Microstructure on Hydrogen Diffusion in Weld and API X52 Pipeline Steel Base Metals under Cathodic Protection
}

\author{
R. C. Souza, ${ }^{1}$ L. R. Pereira, ${ }^{1}$ L. M. Starling, ${ }^{1}$ J. N. Pereira, ${ }^{1}$ T. A. Simões, ${ }^{1,2}$ \\ J. A. C. P. Gomes, ${ }^{3}$ and A. H. S. Bueno ${ }^{1}$ \\ ${ }^{1}$ Mechanical Engineering Department, Universidade Federal de São João Del Rei (UFSJ), 170 Praça Frei Orlando, \\ 36307-352 São João Del Rei, MG, Brazil \\ ${ }^{2}$ Postgraduate Program in Materials Science and Engineering, Universidade Federal da Paraíba (UFPB), João Pessoa, PB, Brazil \\ ${ }^{3}$ Metallurgical and Materials Engineering Department, Universidade Federal do Rio de Janeiro (UFRJ), Ilha do Fundão, \\ Bloco F, Rio de Janeiro, RJ, Brazil \\ Correspondence should be addressed to A. H. S. Bueno; alyssonbueno@ufsj.edu.br
}

Received 28 June 2017; Accepted 7 September 2017; Published 12 October 2017

Academic Editor: Ramazan Solmaz

Copyright (C) 2017 R. C. Souza et al. This is an open access article distributed under the Creative Commons Attribution License, which permits unrestricted use, distribution, and reproduction in any medium, provided the original work is properly cited.

\begin{abstract}
The aim of this research was to evaluate the influence of microstructure on hydrogen permeation of weld and API X52 base metal under cathodic protection. The microstructures analyzed were of the API X52, as received, quenched, and annealed, and the welded zone. The test was performed in base metal (BM), quenched base metal (QBM), annealed base metal (ABM), and weld metal (WM). Hydrogen permeation flows were evaluated using electrochemical tests in a Devanathan cell. The potentiodynamic polarization curves were carried out to evaluate the corrosion resistance of each microstructure. All tests were carried out in synthetic soil solutions NS4 and NS4 + sodium thiosulfate at $25^{\circ} \mathrm{C}$. The sodium thiosulfate was used to simulate sulfate reduction bacteria (SRB). Through polarization, assays established that the microstructure does not influence the corrosion resistance. The permeation tests showed that weld metal had lower hydrogen flow than base metal as received, quenched, and annealed.
\end{abstract}

\section{Introduction}

The great challenge for increasing oil and gas productions has been the need for more detailed studies related to steel for pipelines applications. Therefore, the knowledge about mechanical behavior and microstructure of steels $[1,2]$ for manufacturing these pipelines is important to assure integrity and safety conditions of operation, which is extremely important for oil and gas industry $[3,4]$.

It requires a continual improvement of steels grade API X52 [5] in order to prevent failure. Han et al. [6] showed that the welding procedure involved in the manufacture of pipes might modify the microstructure of the base metal in the region of heat-affected zone (HAZ). Therefore, the mechanical properties in this region are changed.

Metal fractures related to "environmentally induced cracking" are often associated with stress corrosion cracking (SCC) or hydrogen embrittlement (HE) mechanisms [7-9]. Some researchers believe that the process of external cracking of pipelines in contact with soil $\mathrm{pH}$ near neutral is associated with HE instead of SCC $[2,4,10]$.

The initial process in HE is associated with the diffusion of hydrogen through the material. Hydrogen permeation starts when there is atomic hydrogen on the metal surface; therefore, the hydrogen can diffuse into the metal. A large amount of atomic hydrogen can recombine inside the metal forming $\mathrm{H}_{2}$, which is retained in the form of gas bubble under high pressure inside the metal. Furthermore, it is well known that initiation and propagation of cracks occur from these points of hydrogen concentration [11]. Therefore, it is important to evaluate if the hydrogen diffusion occurs differently through different microstructure, such as base metal and weld metal.

In pipelines, the external $\mathrm{HE}$ is associated with the excessive cathodic potential imposed and soils contaminated with sulfate-reducing bacteria (SRB) [12]. Contreras et al. [13] pointed out that minimal amounts of $\mathrm{H}_{2} \mathrm{~S}$ are enough to cause HE. Then, external cracking caused by hydrogen 
TABLE 1: Chemical analysis of the base metal (BM) and the weld metal (WM) API X52 carbon steel.

\begin{tabular}{|c|c|c|c|c|c|c|c|c|c|c|}
\hline \multirow{2}{*}{ Material } & \multicolumn{10}{|c|}{ Components (wt\%) } \\
\hline & $\mathrm{C}$ & $\mathrm{Si}$ & $\mathrm{Mn}$ & $\mathrm{P}$ & S & $\mathrm{Cr}$ & $\mathrm{Ni}$ & Mo & $\mathrm{V}$ & $\mathrm{Cu}$ \\
\hline $\mathrm{BM}$ & 0.28 & 0.33 & 1.11 & 0.03 & 0.02 & 0.05 & 0.02 & 0.01 & 0.001 & 0.02 \\
\hline WM & 0.16 & 0.20 & 0.47 & 0.03 & 0.03 & 0.03 & 0.02 & 0.15 & 0.002 & 0.02 \\
\hline
\end{tabular}

embrittlement could be associated with SRB. These bacteria use sulfate as an oxidizing agent, reducing to sulfide $\left(\mathrm{H}_{2} \mathrm{~S}\right)$. Plus, they can also utilize oxidized sulfur compounds such as thiosulfate and sulfite or even elemental sulfur. In the presence of $\mathrm{H}_{2} \mathrm{~S}$ produced by these bacteria, the reaction of atomic hydrogen recombination to molecular hydrogen is retarded, thereby permitting the diffusion of atomic hydrogen through the metal [10].

Microbiologically influenced corrosion (MIC) is a major problem in many industries, such as oil and gas. According to Xu et al. [14] many attacks of anaerobic MIC can be classified by two types based on the two anaerobic metabolisms: respiration and fermentation. Therefore, the mechanism of SRB involves microorganisms that perform an aerobic respiration. For example, SRB respiration typically uses sulfate as the terminal electron acceptor. Venzlaff et al. [15] reported that $\mathrm{SRB}$ gain biochemical energy for growth by reducing sulfate $\left(\mathrm{SO}_{4}\right)$ to sulfide $\left(\mathrm{H}_{2} \mathrm{~S}, \mathrm{HS}^{-}\right)$with natural organic compounds as electron donors, which are oxidized to $\mathrm{CO}_{2}$ (also referred to as sulfate respiration). However, if the SRB have contact with carbon steel, the Fe acts as an electron donor for its respiration [16]. Then, the reaction involved in anaerobic respiration using $\mathrm{Fe}^{0}$ is $\mathrm{Fe}-\mathrm{Fe}^{2+}+2 \mathrm{e}^{-}$. In the absence of oxygen, electrons must be accepted by a nonoxygen oxidant [13]; thus, $\mathrm{SRB}$ use $\mathrm{SO}_{4}$ as an oxidizing agent. $\mathrm{SO}_{4}$ is reduced to $\mathrm{H}_{2} \mathrm{~S}$ and $\mathrm{HS}^{-}$through the reaction $\mathrm{SO}^{-4}+9 \mathrm{H}^{+}+8 \mathrm{e}^{-}=$ $\mathrm{HS}^{-}+\mathrm{H}_{2} \mathrm{O}$.

Horowitz [17] showed an increase in the amount of hydrogen during permeation tests with the use of sodium thiosulfate solution. The sodium thiosulfate solution allows the generation and stabilization of $\mathrm{H}_{2} \mathrm{~S}$ on the metallic surface. These tests were carried out applying cathodic potentials. According to Pourbaix diagram for $\mathrm{H}_{2} \mathrm{~S}$, when cathodic potential is imposed, the steel is located into $\mathrm{H}_{2} \mathrm{~S}$ domain [18]. Therefore, the sodium thiosulfate is reduced to $\mathrm{H}_{2} \mathrm{~S}$. The reaction depends on the potential applied and the $\mathrm{pH}$ of the solution.

Another problem related to $\mathrm{HE}$ is because the steels, used in the manufacture of pipelines for transporting oil and derivatives, are exposed to excessive cathodic protection. Therefore, cathodic potentials imposed on the external part of pipelines promote hydrogen reduction, which becomes thermodynamically spontaneous on the metal surface [19]. Bueno et al. $[4,12]$ report that API X46 carbon steel exhibited a decreasing ductility as long as cathodic potentials were imposed. This effect was more evident in soil solutions than in NS4 standard solution. The deterioration mechanism is related to the influence of hydrogen. Transgranular cracking occurred even under cathodic conditions where the anodic dissolution of the steel can be considered as negligible.
Recent studies gave emphasis to the influence of the metal structure in hydrogen permeation $[1,2,20]$ and discuss the effective diffusion coefficient. Lan et al. [1] studied the hydrogen permeation behavior in relation to microstructural evolution of low carbon bainitic steel weldments. They have shown that the effective diffusion coefficient in the welded joint is highly affected by the heat input. This is mainly due to coarsening grain and inclusion sizes. Park et al. [2] tested the hydrogen trapping efficiency of API $\mathrm{X} 65$ and showed an increase in order of ferrite/degenerated pearlite, ferrite/bainite, and ferrite/acicular ferrite. Haq et al. [20] showed that, due to hydrogen trapping, X70 medium strip exhibits lower hydrogen diffusivity than the standard Mn strip. This is mainly due to finer ferrite grains and a higher density of carbonitride precipitates. Fischer et al. [21] indicated that under specific circumstances the diffusion of hydrogen cannot be described well by a constant effective diffusion coefficient due to the presence of hydrogen traps and the magnitude of the concentration gradient of hydrogen.

The aim of this paper was to evaluate the influence of microstructure and some inclusions on the susceptibility of hydrogen permeation of API X52 carbon steel (base metal and weld metal) submitted to the cathodic protection system. Different types of microstructures were obtained by heat treatments, such as quenching and annealing under different temperatures. The hydrogen permeation tests in these microstructures were compared and evaluated in the presence of a synthetic modified soil solution NS4 + sodium thiosulfate concentration of $10^{-2} \mathrm{M}$.

\section{Methods and Materials}

The material used was an API X52 pipeline carbon steel under different conditions: base metal, as received; welded metal; base metal after quenching heat treatment; base metal after annealed heat treatment. The evaluation of the chemical composition was carried out by Optical Emission Spectroscopy (OES). Table 1 shows the results in weight percent (wt\%) of the chemical elements present in the base metal (BM) and the weld metal (WM).

The microstructures of the samples were produced by different heat treatment. Base metals were heated at $900^{\circ} \mathrm{C}$ for two hours. Then, the samples were submitted to a quenching process performed in a solution of water, ice, and salt. The annealed samples were left in the oven until it reaches at room temperature. All the tests were performed in triplicate. The specimens and conditions of heat treatment are described in Table 2 .

The metallographic analysis and microstructure characterization were performed according to Bott et al. [24], 
TABLE 2: Terminology and heat treatment conditions of API X52 carbon steel the samples.

\begin{tabular}{lc}
\hline Terminology & Heat treatment conditions \\
\hline Base metal (BM) & As received of the industry \\
Annealed base metal (ABM) & Heated at $900^{\circ} \mathrm{C}$, cold in the oven \\
Quenching base metal (QBM) & Heated at $900^{\circ} \mathrm{C}$, cold in water, ice, and salt \\
Weld metal (WM) & Removed from the welded joint of the pipeline as received \\
\hline
\end{tabular}

in order to reveal the microstructures obtained after the heat treatments described in Table 2. The metallographic analyses were carried out by optical microscopy (OM, Leica, model DM 2500P) and scanning electron microscopy (SEM, Hitachi, model TM 3000). The samples were embedded in Bakelite, ground with $\mathrm{SiC}$ paper up to 1200 grit, polished with diamond paste up to $0.25 \mu \mathrm{m}$, and polished with $0.04 \mu \mathrm{m}$ silica suspension. Etching of the metal surface was done using Nital 2\% for five seconds. The samples used for inclusions analysis were evaluated without chemical attack.

The presence of austenite-martensite phases was detected by SEM after double electrolytic attack. The following steps were used to the attack: initially $5 \mathrm{~g}$ EDTA, $0.5 \mathrm{~g}$ of NaF, and $100 \mathrm{ml}$ of distilled water at $5 \mathrm{~V}$ for 15 seconds were used; secondly $5 \mathrm{~g}$ of picric acid and $25 \mathrm{~g} \mathrm{NaOH}$ were used; finally, $100 \mathrm{ml}$ of distilled water at $100 \mathrm{~V}$ for 5 seconds was used.

The hardness tests were conducted to supplement the materials characterization. These were performed on Rockwell B scale using sphere $1 / 16^{\prime \prime}$ with a load of $100 \mathrm{~kg}$ and Rockwell C using diamond cone with a load of $150 \mathrm{~kg}$.

The electrochemical test performed was potentiodynamic polarization curves. The potentiostat used in polarization tests was AUTOLAB models: $\mu$ Autolab type III/FRA 2 and PGSTAT $128 \mathrm{~N}$ coupled to computers NOVA 1:10 software. The scan rate adopted was $1.0 \mathrm{mV} \cdot \mathrm{s}^{-1}$, and the applied potential range covered a value of $-1.5 \mathrm{~V}$ to $0.5 \mathrm{~V}$. The measurements were performed at room temperature $\left(25^{\circ} \mathrm{C} \pm\right.$ $3^{\circ} \mathrm{C}$ ). The cell used was a conventional three-electrode cell, being platinum as counter electrode, saturated calomel (SCE) as reference electrode, and the working electrode (samples of API X52 carbon steel). The specimens for the electrochemical tests were cut, embedded in cold resin, and ground with $\mathrm{SiC}$ paper up to 600 grit. The exposed area of the samples for permeation tests at Devanathan cell was $0.75 \mathrm{~cm}^{2}$. For polarization experiments, the exposed area was $1 \mathrm{~cm}^{2}$.

Synthetic soil solution, also called NS4 solution, was used during the test, to simulate a synthetic soil, with $\mathrm{pH}$ around 8.4. The solution was made according to Parkins et al. [25]. The composition was (in g/l) $\mathrm{KCl}$ : $0.122, \mathrm{NaHCO}_{3}$ : $0.483, \mathrm{CaCl}_{2}: 0.093$, and $\mathrm{MgSO}_{4}: 0.131$. Plus, the synthetic solution NS4 + sodium thiosulfate was used to study the effect caused by sulfate-reducing bacteria. It was prepared with a concentration of $10^{-2} \mathrm{M}$ of sodium thiosulfate in the standard NS4 solution. Some studies [26] adjust the $\mathrm{pH}$ to $6,5-7$, in order to evaluate soils with this characteristic by bubbling a mixture of $\mathrm{CO}_{2}$ and $\mathrm{N}_{2}$.

The hydrogen permeation tests were carried out with the most aggressive solution, NS4 + sodium thiosulfate. The potentiostat used in hydrogen permeation tests was AUTOLAB models: $\mu$ Autolab type III/FRA 2 and PGSTAT $128 \mathrm{~N}$ coupled to computers NOVA 1:10 software. The Devanathan cell was utilized in the test using specimens with a thickness of $2 \mathrm{~mm}$. Both sides of the steel specimen were in contact with different solutions controlled by independent potentiostats. The anodic side of the cell was filled with $1 \mathrm{M}$ of $\mathrm{NaOH}$ solution and the cathodic side was filled with NS4 + sodium thiosulfate solution. The counter electrode of the anodic side cell was attached to a computer to measure the anodic current. Hydrogen permeation tests were carried out in the following steps.

(1) Assemble the hydrogen permeation Devanathan cell containing the steel specimen.

(2) $1 \mathrm{M} \mathrm{NaOH}$ solution was introduced in the anodic side and the system was stabilized at the open circuit potential (OCP).

(3) Application of anodic potential $100 \mathrm{mV}$ above the free corrosion potential was done at the anodic side until the anodic passive current density became stable and below $1 \mathrm{~A} / \mathrm{cm}^{2}$.

(4) Introduction of NS4 solutions was done in the cathodic side which remained at the open circuit potential during $20 \mathrm{~h}$.

(5) Application of cathodic potential of $-1.5 \mathrm{~V}$ (ECS) was done for $24 \mathrm{~h}$. The test piece used was a flat plate of API X52 steel polished with diamond paste on both sides, with thickness and permeation section area constant. The cathodic potential applied of $-1.5 \mathrm{~V}$ below OCP was carried out in order to simulate cathodic protection system [27], once ISO 15589-1 indicates that from values lower than $-1.2 \mathrm{~V}$ the steel is already suffering effects of hydrogen embrittlement.

The diffusion coefficient $(D)$, in transient state, can be measured through various different methods as found in the literature. In this research, the three most common methods were used: Time Lag, Breakthrough, and Fourier, calculated according to literature $[20,28,29]$.

\section{Results and Discussions}

3.1. Chemical Analysis. The API 5L standard [5] classifies carbon steel for the manufacture of pipes used in pipelines transportation system in the petroleum and natural gas industries. The requirements used in the standard are divided into two levels for seamless and welded pipelines: PSL1 and PSL2. The PSL1 requirement is a loose standard quality for line pipe, whereas PSL2 contains additional testing requirement and stricter chemical physicals, along with different ceiling limits of mechanical properties, and requires Charpy impact testing conditions. According to Table 3, base metal reaches the chemical requirement of PSL1; however the same is nonconformity with PSL2 due to the carbon content limits 
TABLE 3: Chemical composition specification of API 5L PSL1 and PSL2 (wt\%).

\begin{tabular}{lccccc}
\hline API 5L & Pipelines & $\mathrm{C}$ & $\mathrm{Mn}$ & $\mathrm{P}$ & $\mathrm{S}$ \\
\hline \multirow{2}{*}{ PSL1-X52 } & Seamless & 0.280 & 1.400 & 0.030 & 0.030 \\
& Welded & 0.260 & 1.400 & 0.030 & 0.030 \\
\multirow{2}{*}{ PSL2-X52N } & Seamless & 0.240 & 1.400 & 0.025 & 0.015 \\
& Welded & 0.220 & 1.400 & 0.025 & 0.015 \\
\hline
\end{tabular}

TABLE 4: Measures hardness of the samples studied.

\begin{tabular}{lc}
\hline Test condition & Hardness \\
\hline API X52-BM & $84 \mathrm{HRB}$ \\
API X52-WM & $80 \mathrm{HRB}$ \\
API X52-ABM & $67 \mathrm{HRB}$ \\
API X52-QBM & $24 \mathrm{HRB}$ \\
\hline
\end{tabular}

(Table 1). Weld metal is in accordance with the required specifications of PSL2 chemical composition.

3.2. Metallographic Features. The metallographic characterization of the samples was conducted on all heat treatment conditions specified on Table 2: base metal (BM), weld metal (WM), annealed base metal (ABM), and quenched base metal (QBM). The hardness tests were performed to complement the materials characterization, as shown in Table 4. Figure 1 shows optical microscopy image of the positions where the metallographic analyses were performed.

Figure 2 presents the interface between WM and HAZ, showing the difference between the microstructures. HAZ presents mainly pearlite grains, shown to be affected by the heat produced during the welding process. According to Vargas-Arista et al. [30] SEM analysis, HAZ generated by the welding thermal cycle showed a complex recrystallized microstructure located near to the fusion line, formed by coarse-grained ferrite, acicular ferrite, small discontinuous pearlite colonies, and few bainite grains.

Base metal (Figure 3) presented heterogeneous distribution of ferrite and fine pearlite grains with grain boundaries well-defined. This microstructure arrangement presents an intermediary value for hardness in Table 4 . The same microstructure for the API X52 steel was found in several other literatures $[31,32]$, owning a ferritic-pearlitic combination.

The weld metal in region 4 (Figure 4) showed a microstructure formed by low recrystallization, where it is possible to observe pearlitic microstructure and a decrease in grain size with degenerated pearlite regions. This fact was discussed by Park et al. [2] and can be explained because the degenerated pearlite structure, without the banding pattern, was different from pearlite evolved by normalizing and slow cooling treatment. The cooling rate in the weld metal was higher than necessary to form typical pearlite; thus the carbon diffusion was not enough to create lamellar structure of cementite.

Figure 5 shows the heat-affected zone (HAZ), where there is a great similarity with the microstructure of the BM; the

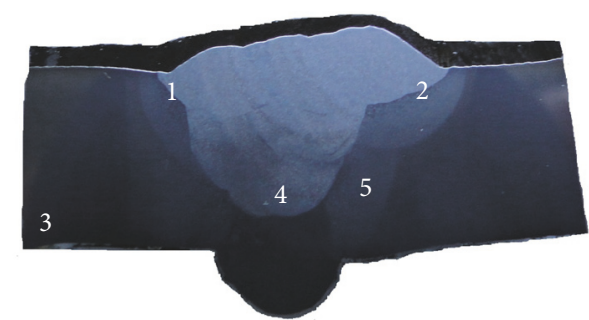

FIGURE 1: Optical microscopy image (low magnification) of the weld zone in API X52 carbon steel and regions analyzed.

little difference is due to the thermal effect caused by the deposition of the weld bead, which provides an increase grain boundary density in the microstructure of HAZ.

Scanning electron microscopy (SEM) was performed at 3 different positions at the welded joint, as shown in optical image on Figure 6. The BM (Figure $7(\mathrm{a})$ ) presents predominate phases of ferrite and pearlite. The HAZ and WM (Figures 7(b) and 7(c)) present phases of ferrite and pearlite with constituents of martensite/austenite (M/A); this constituent cannot be observed by optical analysis (OM), called constituent $\mathrm{M} / \mathrm{A}$ or micro phase $\mathrm{M} / \mathrm{A}$, regions of microscopic dimensions presented in C-Mn steels, and low alloy that consists of cells stabilized austenite. Chatzidouros et al. [31] emphasize that most pipeline steels are manufactured using thermomechanical processes that involve multiple heating and rolling stages which favor the formation of $\mathrm{M} / \mathrm{A}$ constituents in low carbon steels. This micro constituent directly affects the tenacity of material due to high hardness and fragility, where the high density of discordances in the submicrostructure contributes to this formation. The $\mathrm{M} / \mathrm{A}$ sites are mostly present in the grain boundaries of ferrite and bainite grains shown in Figure $7(\mathrm{c})$; however they occasionally could also be observed within the phase of pearlite between the cementite lamellar.

Observations of the materials, without chemical attack, revealed the presence of a significant amount of inclusions, as shown in Figure 8.

EDS technique was used to evaluate the composition of the inclusions. Figure 9 shows the WM inclusions analyses. Therefore, the inclusions presented in API X52 carbon steel showed, besides aluminum and calcium, significant concentrations of S and Mn. Haq et al. [20] have concluded that MnS inclusions are considered strong irreversible trapping sites for hydrogen, working as follows: during the solidification of steel, Mn can combine with S giving rise to $\mathrm{MnS}$ inclusions. The behavior of inclusions/matrix metal interface is reported by literature as strong trapping sites for hydrogen, consequently decreasing the hydrogen flux through the material.

After heat treatments, SEM analyses show that the ABM (Figure 10(a)) and BM (Figure 7(a)) present the same microstructure; however the BM grain size is slightly lower. This is evidenced by the greater hardness submitted by BM. The quenched base metal specimens presented martensitic structure, but due to the low carbon they have noted some ferrite sites, as proved in Figure 10(b). The heat treatment changes can also be noted in hardness values (Table 4) where 


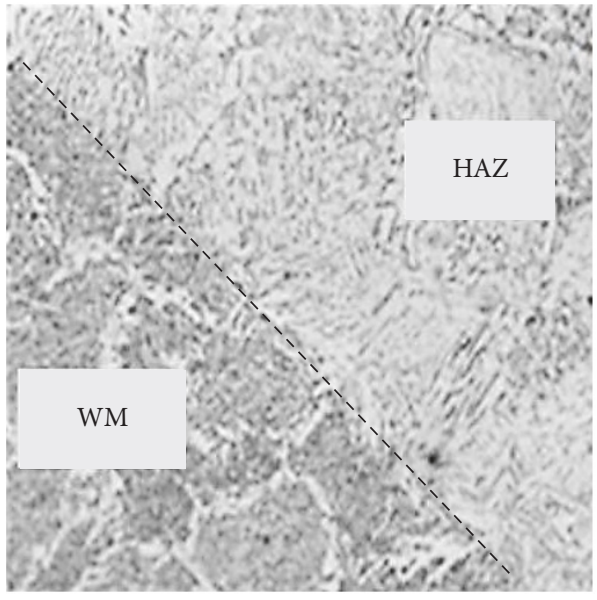

(a)

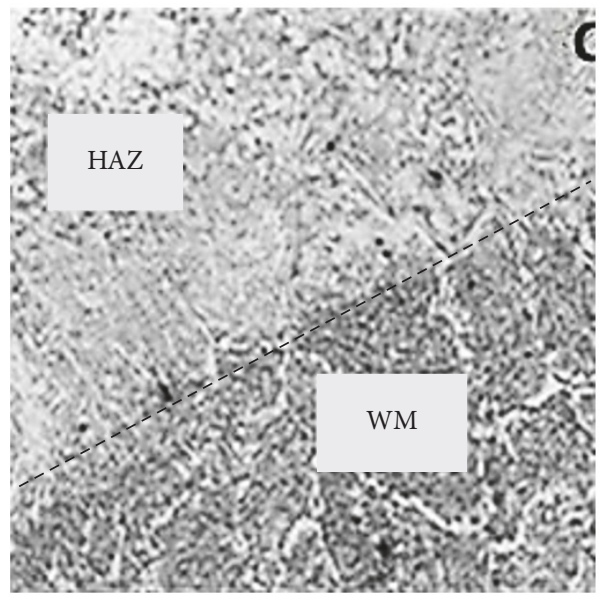

(b)

Figure 2: Optical microscopy image of the interface between weld metal and the heat-affected zone: (a) at position 1; (b) at position 2 (both with magnification of 200x).

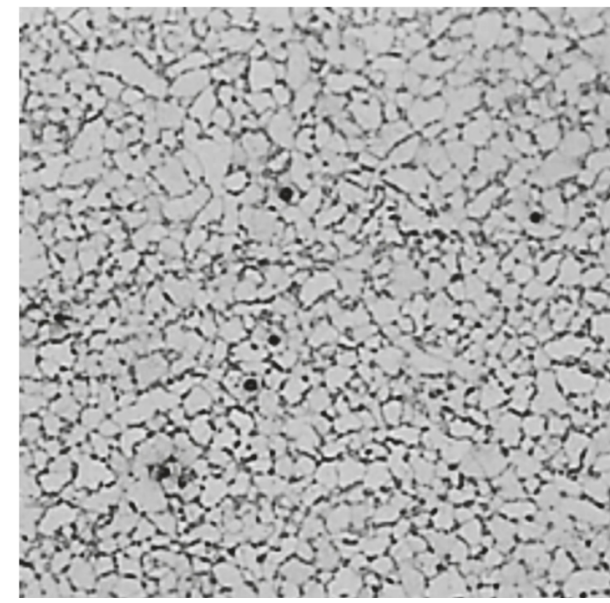

(a)

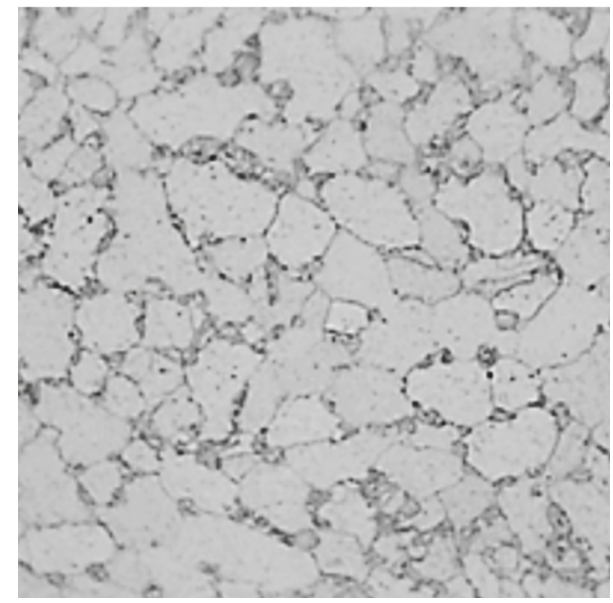

(b)

Figure 3: Optical microscopy image of base metal at position 3 under different magnifications: (a) 200x and (b) 500x.

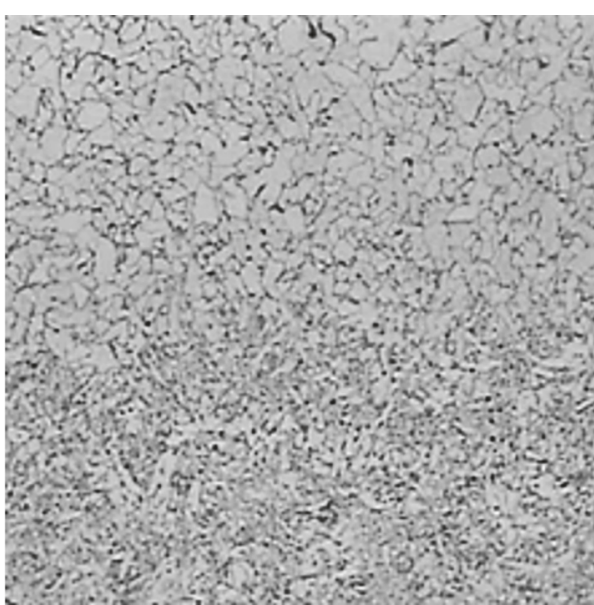

(a)

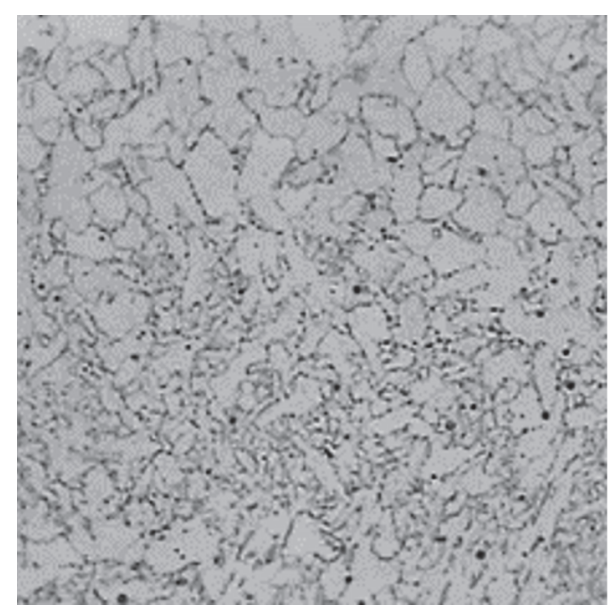

(b)

FIGURE 4: Optical microscopy image of weld metal at position 5 under different magnifications: (a) 200x and (b) 500x. 
TABLE 5: OCP, current density at $50 \mathrm{mV}$ and $100 \mathrm{mV}$ above the OCP.

\begin{tabular}{|c|c|c|c|c|c|c|c|}
\hline $\begin{array}{l}\text { Test } \\
\text { condition }\end{array}$ & Solution & $\mathrm{pH}$ & $\begin{array}{c}\text { OCP } \\
(\mathrm{ECS})\end{array}$ & $\begin{array}{c}E \\
50 \mathrm{mV} \\
\text { above OCP } \\
(\mathrm{mV})\end{array}$ & $\begin{array}{c}i \\
50 \mathrm{mV} \text { above OCP } \\
\left(\mu \mathrm{A} / \mathrm{cm}^{2}\right)\end{array}$ & $\begin{array}{c}E \\
100 \mathrm{mV} \text { above OCP } \\
(\mathrm{mV})\end{array}$ & $\begin{array}{c}i \\
100 \mathrm{mV} \text { above OCP } \\
\left(\mu \mathrm{A} / \mathrm{cm}^{2}\right)\end{array}$ \\
\hline \multirow{2}{*}{$\mathrm{BM}$} & NS4 & 8.4 & -0.716 & -0.666 & $2.597 E-5$ & -0.616 & $6.796 E-5$ \\
\hline & NS4 + thiosulfate & 8.6 & -0.766 & -0.716 & $8.847 E-5$ & -0.667 & $2.175 E-4$ \\
\hline \multirow{2}{*}{ WM } & NS4 & 8.1 & -0.695 & -0.645 & $6.247 E-5$ & -0.595 & $1.185 E-4$ \\
\hline & NS4 + thiosulfate & 8.8 & -0.758 & -0.708 & $7.617 E-5$ & -0.658 & $2.105 E-4$ \\
\hline QBM & $\mathrm{NS} 4+$ thiosulfate & 7.9 & -0.743 & -0.692 & $1.125 E-4$ & -0.642 & $3.231 E-4$ \\
\hline $\mathrm{ABM}$ & NS4 + thiosulfate & 8.3 & -0.766 & -0.717 & $8.401 E-5$ & -0.667 & $2.568 E-4$ \\
\hline
\end{tabular}

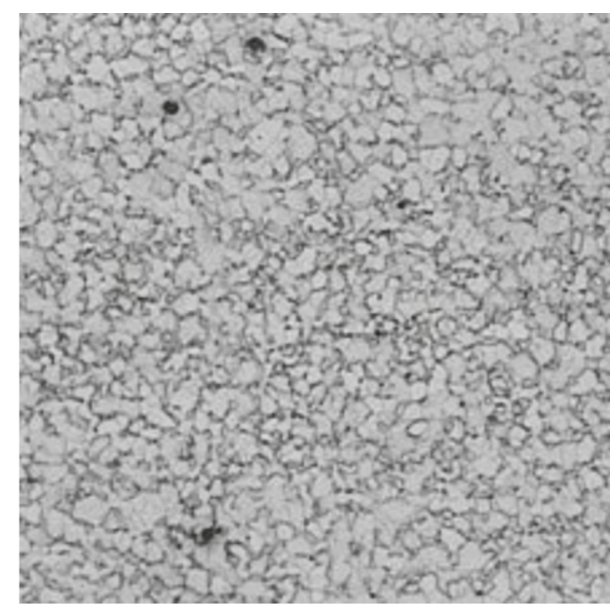

(a)

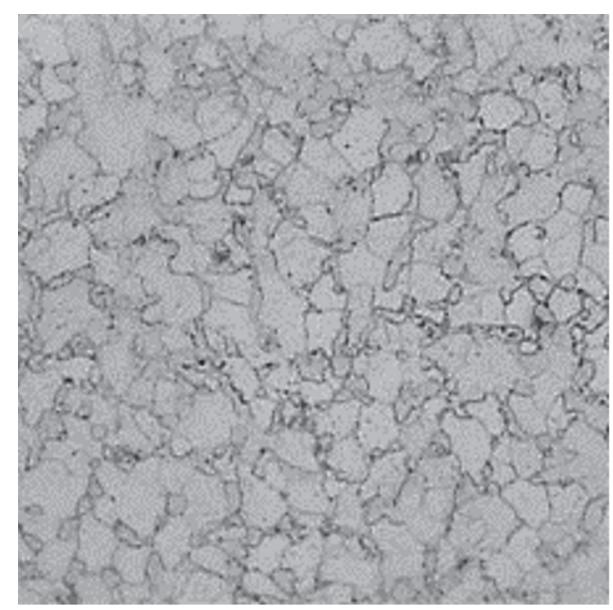

(b)

FIGURE 5: Optical microscopy image of heat-affected zone at position 5 under different magnifications: (a) 200x and (b) 500x.

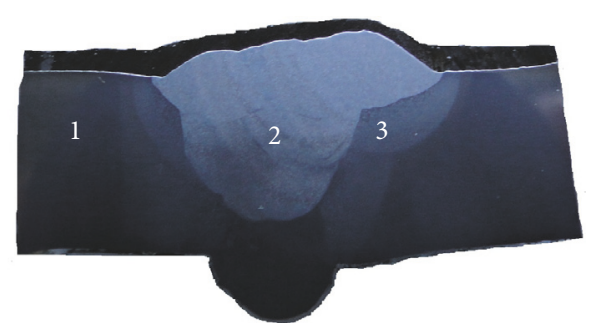

FIgURE 6: Optical image of the weld zone in API X52 carbon steel and regions analyzed by SEM secondary electron image with high magnification.

there is a significant difference in hardness between QBM and ABM.

3.3. Polarization. The cathodic and anodic polarization curves were carried out in order to evaluate if the microstructure could affect the corrosion resistance of the API X52 carbon steel. Curves were obtained in the solutions NS4 and NS4 + sodium thiosulfate shown in Figure 11, related to BM and WM. The anodic current density was highest for NS4 + sodium thiosulfate solution, and it may be attributed to reduction reaction of sodium thiosulfate that converted into $\mathrm{H}_{2} \mathrm{~S}$. This makes it more aggressive than the NS4 standard solution. Thus, the electrochemical tests for the specimens $\mathrm{ABM}$ and QBM were performed only in this solution (Figure 12 and Table 5). Table 5 shows the open circuit potential (OCP) in each test condition as well as the values of current density at $50 \mathrm{mV}$ and $100 \mathrm{mV}$ (SCE) above open circuit potential (OCP).

All the samples showed active dissolution in all tested conditions. Therefore, any domain of passivation in a range of $700 \mathrm{mV}$ of anodic polarization was not observed. The cathodic currents density observed, in all tests, can be attributed to the reduction reactions of hydrogen and oxygen.

It is possible to note a significant variation of the density current occurred when the sodium thiosulfate was added, showed on Table 5. The addition of thiosulfate accentuated the corrosion process, anodic density current increase with respect to the solution without sodium thiosulfate. It proves that the solutions with sodium thiosulfate presented a corrosion potential more anodic, becoming more aggressive, which evidence the results obtained in the polarization curves.

The open circuit potential (OCP) of Figures 11 and 12 and Table 5 was analyzed according to the Pourbaix electrochemical equilibrium diagram for the system $\mathrm{Fe} / \mathrm{H}_{2} \mathrm{O}$, at $25^{\circ} \mathrm{C}$ [18]. All the specimens, in both solutions, presented OCP within the domain of corrosion and below the equilibrium line $\mathrm{H} / \mathrm{H}^{+}$. In this case, the reactions of $\mathrm{Fe} / \mathrm{Fe}^{2+}$ anodic dissolution 


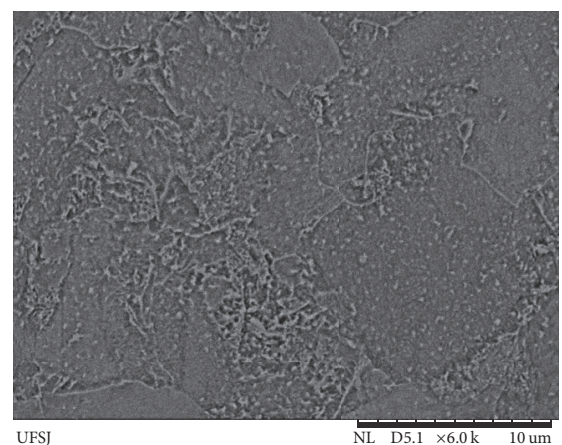

(a)

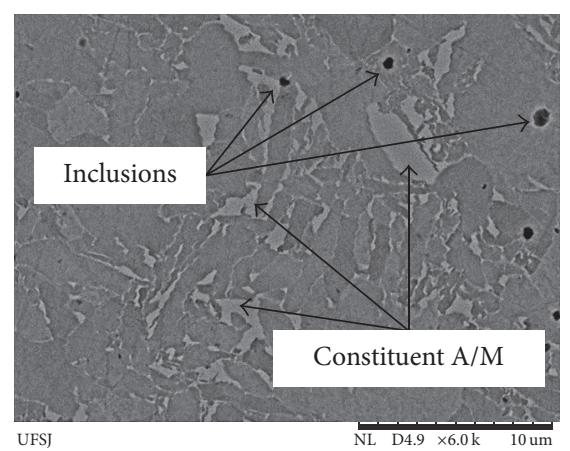

(b)

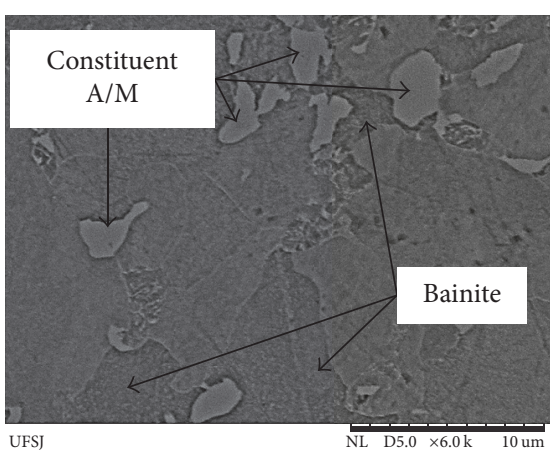

(c)

FIGURE 7: SEM secondary electron image of (a) base metal at zone 1; (b) weld metal at zone 2, showing the constituent M/A and the inclusions; (c) HAZ at zone 3, showing the constituent M/A and regions formed by bainite.

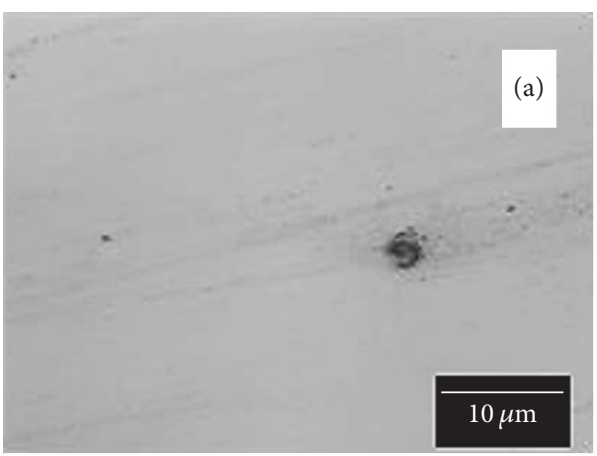

(a)

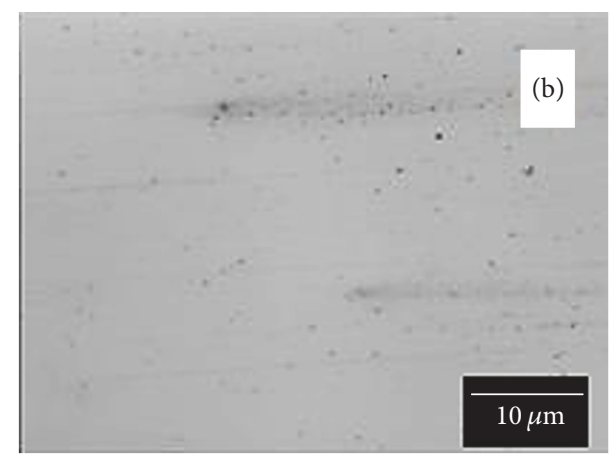

(b)

FIGURE 8: Optical image of (a) base metal and (b) weld metal, both without chemical attack.

and reduction of hydrogen are thermodynamically spontaneous. Thus, all of samples showed effect of active dissolution, being within the domain of corrosion with solubility of $\mathrm{Fe}^{2+}$ ion, as well as the reaction of hydrogen reduction on the metal surface. In addition, it is possible to note that the anodic current densities increase in relation to the applied potential above $50 \mathrm{mV}$ and $100 \mathrm{mV}$ of the OCP, proving that all samples presented active dissolution. The anodic current densities, measured at 50 and $100 \mathrm{mV}$ above OCP in all specimens tested with NS4 + thiosulfate solution, presented similar values (Table 5). In other words, it is possible to conclude that different microstructures have no significant effects about corrosion resistance.

3.4. Hydrogen Permeation. Figure 13 presents the permeation test of all specimens. They were performed by hydrogen permeation using an aggressive solution, namely, NS4 + sodium thiosulfate, already evidenced in polarization test and by some authors [33-35], as a solution of soil synthetic contaminated with SRB. The permeation tests with cathodic potential applied of $-1.5 \mathrm{~V}$ below OCP were carried out in order to simulate cathodic protection system.

The solution NS4 + sodium thiosulfate was able to induce absorption and permeation of hydrogen in all materials tested and it was used to simulate the effect of $\mathrm{H}_{2} \mathrm{~S}$ in synthetic soil solution. The effect of $\mathrm{H}_{2} \mathrm{~S}$ can be compared to the effect of SRB in the same environment, preventing $\mathrm{H}_{0}$ from turning into $\mathrm{H}_{2}$. Due to the addition of sodium thiosulfate, the potential of the cathode side in contact with the API X52 carbon steel was located within the domain of stability of $\mathrm{H}_{2} \mathrm{~S}$ (Figure 14). Therefore, there is an increase in the activity of ions and reduction hydrogen on the steel surface.

As found in the literature, there are different factors that involve the hydrogen flow through the material. During the initial stage, the permeation process resembles a stationary permeation behavior, but in a second stage a progressive increase of current starts as the time goes by. However, this rise of current occurs differently in the carbon steel. Thus, this difference in the current flow is probably due to the microstructural characteristics, like the carbide form and size of grains differentiated among the studied conditions $[1,28]$.

Hydrogen diffusion coefficient in steel matrix generally is very small at low temperatures. Therefore, most of hydrogen is retained not in the unit cells interstices but in different sites commonly called traps. These traps have been related to microstructural features such as dislocations, interfaces, vacancies, impurity atoms, micro voids, or any other lattice defect $[19,36]$. The trap densities are inversely proportional to the diffusion coefficients [20]. 


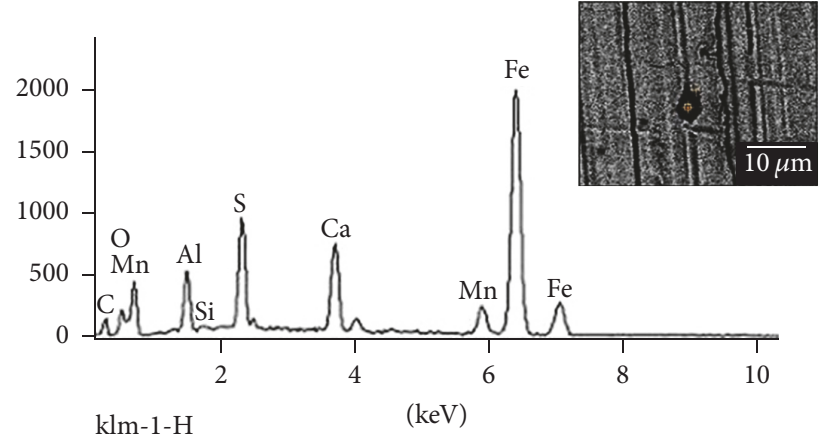

(a)

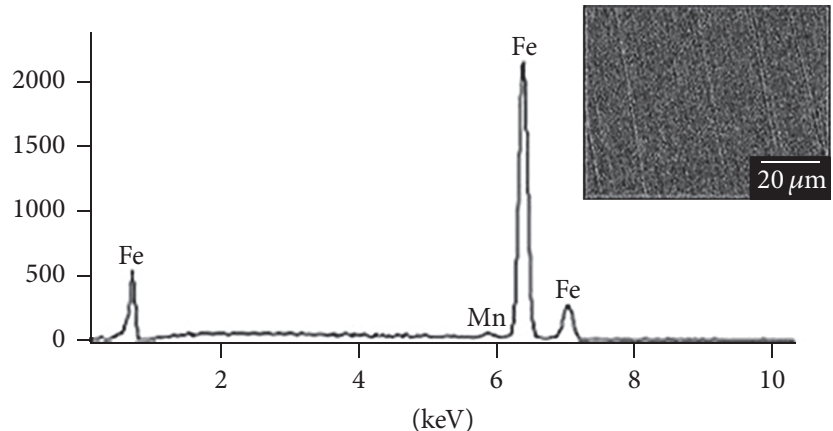

klm-6-C

(b)

FIGURE 9: SEM secondary electron image and EDS spectra of (a) inclusions presented in the API X52 carbon steel and (b) an area without inclusions.

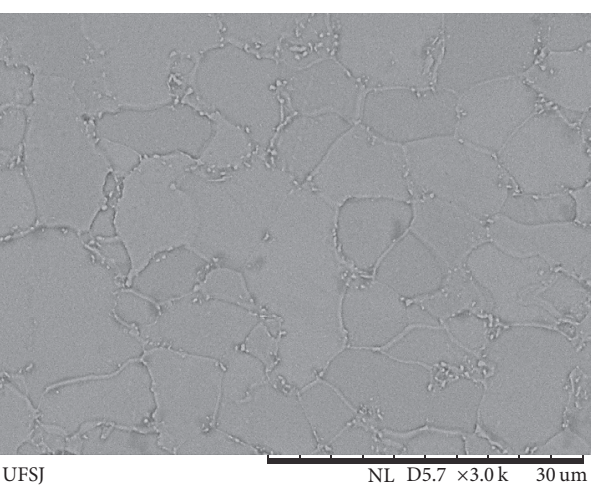

(a)

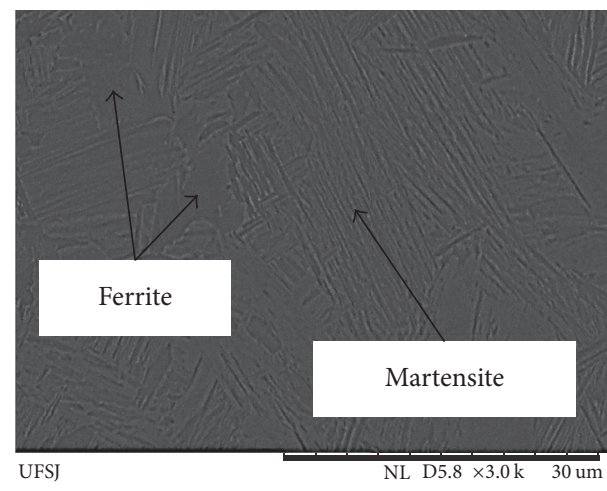

(b)

FIGURE 10: SEM secondary electron image of base metal after two different heat treatments: (a) annealed and (b) quenched.
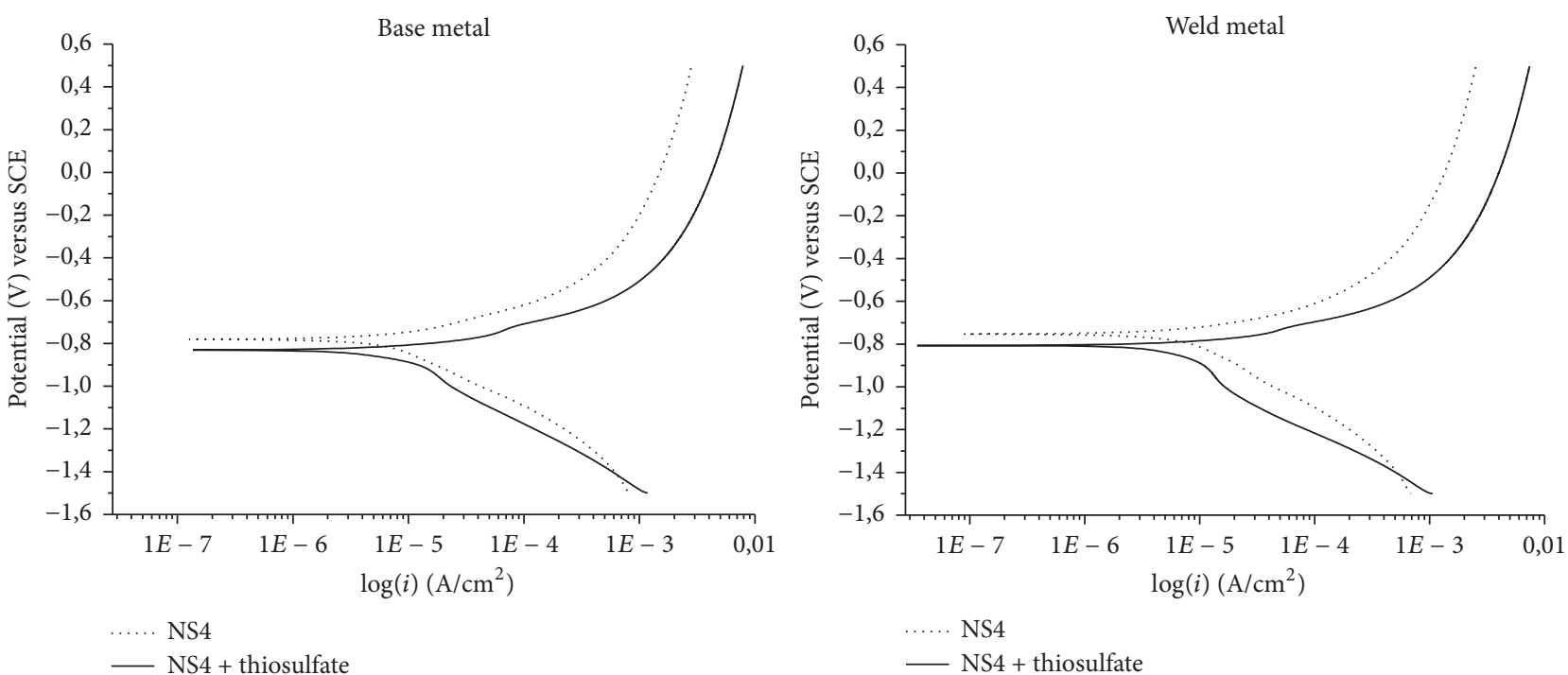

FIGURE 11: Anodic and cathodic polarization curves of the base metal (BM) and weld metal (WM) of the API X52 carbon steel immersed in the NS4 synthetic soil solution and NS4 + sodium thiosulfate $10^{-2} \mathrm{M}$ modified solution. 


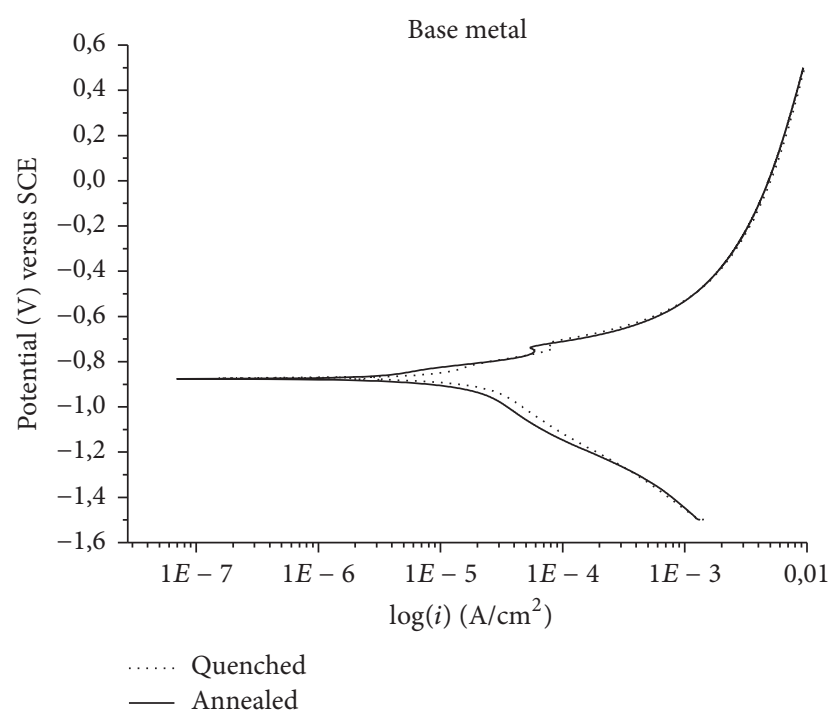

FIgURE 12: Anodic and cathodic polarization curves of the annealed base metal (ABM) and quenched base metal (QBM) of the API X52 carbon steel immersed in the NS4 + sodium thiosulfate $10^{-2} \mathrm{M}$ modified solution.

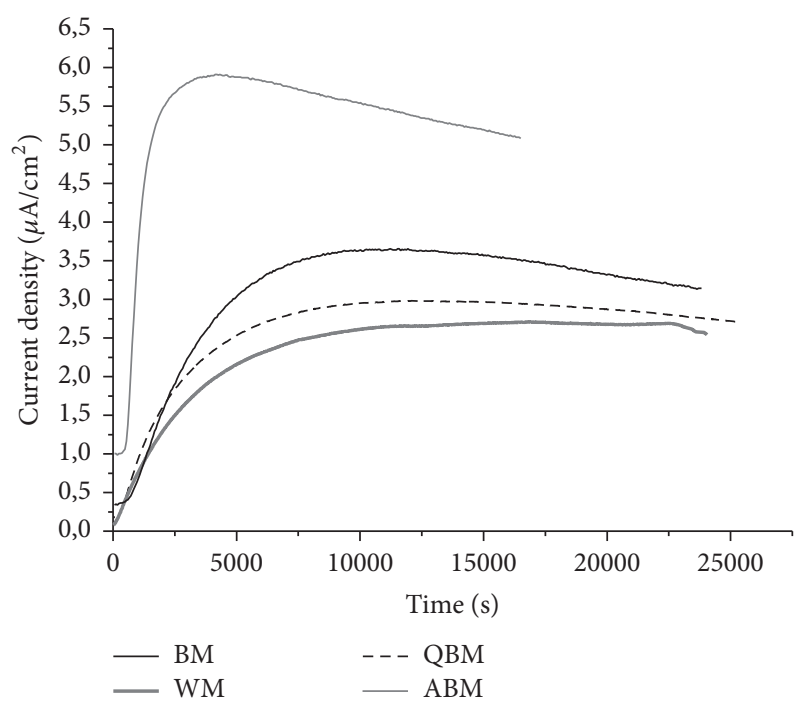

Figure 13: Hydrogen permeation, base metal (BM), weld metal $(\mathrm{WM})$, annealed base metal (ABM), and quenched base metal (QBM) of API X52 carbon steel.

Literature $[37,38]$ reports that when the carbon steel is submitted to a heat treatment, it changes the structural arrangement of the carbides $\left(\mathrm{Fe}_{3} \mathrm{C}\right)$ which assume different forms for each one. These different forms promote significantly modifications on permeability properties in relation to the diffusion constant and the solubility of hydrogen in the carbon steel. The typical pearlite, formed by both cementite (carbide) and ferrite, in lamellar shape, is a weak hydrogen trap due to its continuous interphase which acts as a freeway to the hydrogen, easing the diffusivity. This feature is present in the $\mathrm{BM}$ and $\mathrm{ABM}$ and it is one of the reasons that they display high diffusion compared to the other two (Figure 13).

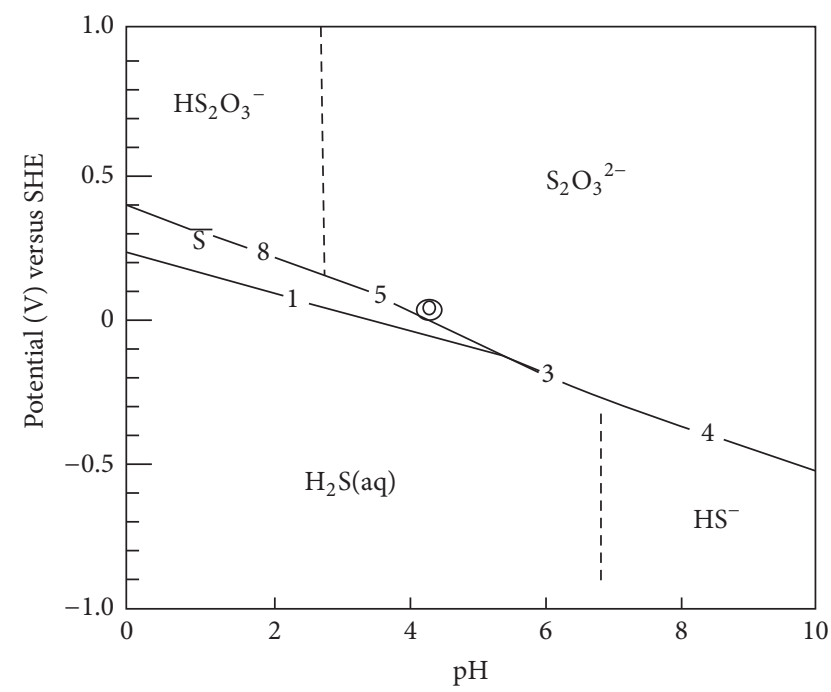

FIgURE 14: $E$ versus $\mathrm{pH}$ for sodium thiosulfate and $\mathrm{H}_{2} \mathrm{~S}$ thermodynamic equilibrium in aqueous solutions [18].

TABLE 6: Values of permeation in different microstructures of API X52 carbon steel.

\begin{tabular}{lc}
\hline Sample & Highest current density $\left(\mu \mathrm{A} / \mathrm{cm}^{2}\right)$ \\
\hline ABM & 5.9101 \\
BM & 4.1086 \\
QBM & 3.6555 \\
WM & 2.7130 \\
\hline
\end{tabular}

On the other hand the presence of an irregular thin cementite, which holds hydrogen inside the metal acting as a trap, contributes to the lower diffusivity as is shown by WM. Similar results were obtained by Ramunni et al. [38].

There are reports in the literature that affirm that Mn, S, and other inclusions, as shown in Figure 9, are some of the reasons that contribute to variance of ease with which the hydrogen is solubilized or diffused on metallic materials solid at room temperature [20,39]. In other words, MnS inclusions are considered strong irreversible trapping sites for hydrogen, being reported by literature as strong trapping sites for hydrogen, consequently decreasing the hydrogen flux through the material. However, this research had not been able to perform the hydrogen permeation tests directly on the inclusion to be sure that only they would affect the hydrogen permeation flux.

The data of the permeation tests are listed in Table 6, showing the highest density current and the time needed to reach that for each microstructure of the API X52 carbon steel.

These values are in accordance with other authors [2, $38,39]$. These authors report that so many parameters can influence the hydrogen diffusion into the microstructure. The hydrogen permeation cannot be considered constant inside the metal during the Devanathan cell test because of the hydrogen trapping process. Thus, only an apparent diffusion coefficient can be evaluated. Moreover, the microstructure, inclusions, dislocations, grain boundaries, grains shapes, 


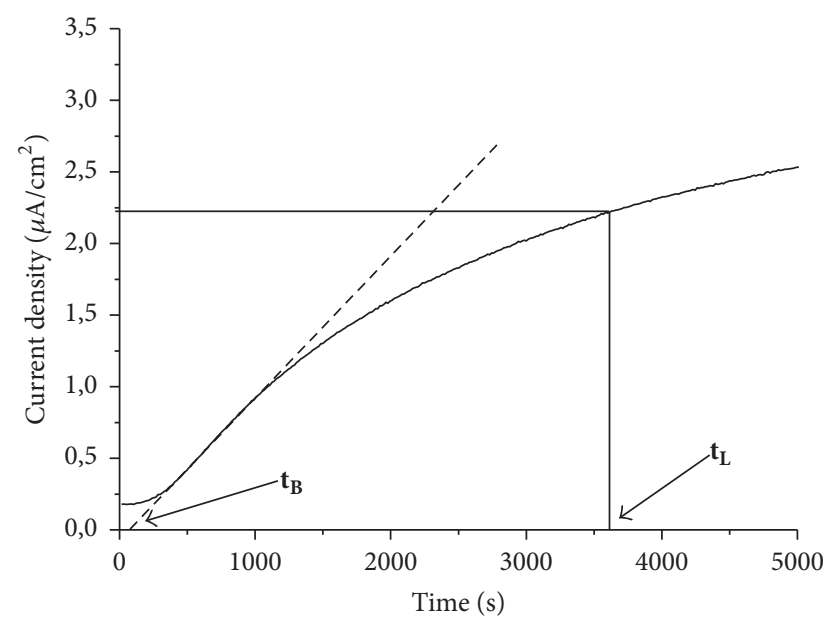

(a)

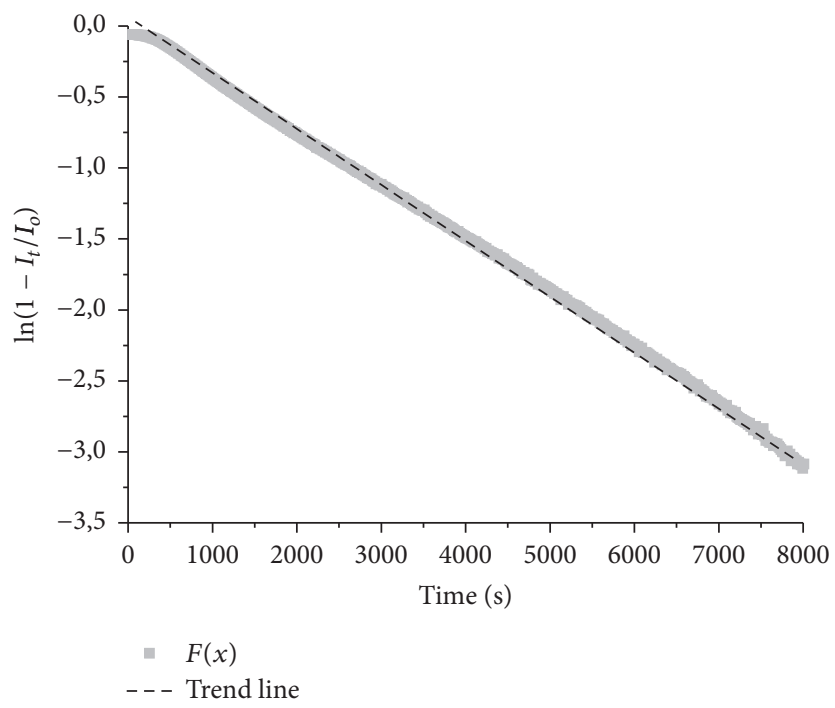

(b)

FIGURE 15: Effective diffusion coefficient of hydrogen in API X52 steel using different methods: (a) Time Lag, $\mathbf{t}_{\mathrm{L}}$, and Breakthrough, $\mathbf{t}_{\mathbf{B}}$; (b) Fourier.

TABLE 7: Data obtained from analysis of the hydrogen permeability plot for all samples of API X52 steel.

\begin{tabular}{|c|c|c|c|c|c|c|c|}
\hline \multirow{3}{*}{ Sample } & \multirow{3}{*}{$I_{\infty}(\mu \mathrm{A})$} & \multirow{3}{*}{$\operatorname{Time}^{*}(\mathrm{~s})$} & \multicolumn{5}{|c|}{ Effective diffusion coefficient $\left(D^{\text {eff }}\right)\left(\times 10^{-4} \mathrm{~mm}^{2} \cdot \mathrm{s}^{-1}\right)$} \\
\hline & & & \multicolumn{2}{|c|}{ Time Lag } & \multicolumn{2}{|c|}{ Breakthrough } & \multirow{2}{*}{$\begin{array}{c}\text { Fourier } \\
D_{\text {app }}\end{array}$} \\
\hline & & & $\mathbf{t}_{\mathrm{L}}(\mathrm{s})$ & $D^{\text {eff }}$ & $\mathbf{t}_{\mathrm{B}}(\mathrm{s})$ & $D_{\text {app }}$ & \\
\hline $\mathrm{BM}$ & 2.983 & 12300 & 2610 & 2.554 & 590 & 4.460 & 4.902 \\
\hline WM & 2.045 & 16850 & 3900 & 1.709 & 810 & 3.249 & 3.010 \\
\hline $\mathrm{ABM}$ & 4.456 & 4680 & 1020 & 6.536 & 310 & 8.489 & 15.040 \\
\hline QBM & 2.751 & 11160 & 3180 & 2.096 & 545 & 4.829 & 4.025 \\
\hline
\end{tabular}

${ }^{*}$ Time required for permeation current stabilization $\left(I_{\infty}\right)$.

vacancies, interfaces with nonmetallic inclusions, precipitated particles, and void can act as traps and affect hydrogen movement through the material. Then, hydrogen diffusibility is associated with the diffusion process controlled by Fick's laws and physic-chemical reaction of hydrogen with traps inside the bulk.

The effective diffusion coefficient ( $\left.D^{\text {eff }}\right)$ is an important parameter used in studies of chemical elements diffusion on solid and liquid matrices. In the present work, the coefficient was studied for all four different samples submitted to 3 different methods to calculate. The methods known as Time $\mathrm{Lag}$ and Breakthrough are employed to estimate the $D^{\text {eff }}$ values using specific points of the permeation curves. Fourier method is more complex once it uses all the data points from the transient part of the permeation curve to determine $D^{\mathrm{eff}}$; however, the method is considered more accurate. Figure 15 shows the hydrogen permeation results for BM samples using all three methods. Permeation times used to calculate $D^{\text {eff }}$ are represented by $\mathbf{t}_{\mathbf{L}}$ (Time Lag) and $\mathbf{t}_{\mathbf{B}}$ (Breakthrough) in Figure 15(a). Fourier method was used to estimate $D^{\text {eff }}$ from the graphic in Figure 15(b) [28].

Table 7 summarizes all the data collected from electrochemical permeation tests, for all the conditions. Samples that presented higher stationary permeation currents $\left(I_{\infty}\right)$ also showed higher values of effective diffusion coefficient $\left(D^{\text {eff }}\right)$. WM obtained the lowest effective diffusion coefficient followed by ABM, BM, and QBM, respectively.

The values obtained for $D^{\text {eff }}$ are in accordance with the literature in Table 8. Comparing Tables 7 and 8, Time Lag method presented the lowest values of $D^{\text {eff }}$, while Breakthrough and Fourier methods showed similar values, except for QBM. In contrast, literature data showed less variation and Fourier method produced low values for API X52 steel. The distinct results obtained could be associated with different parameters used for the tests. Also, the different steels used can imply higher quantities of alloy elements present in the composition, increasing the amount of precipitates, which contributes to the reduction of the hydrogen diffusion.

3.4.1. Annealed Base Metal (ABM). The highest hydrogen flux occurred in the ABM samples as evidenced in Figure 13 and Table 6. Annealed samples showed in the micrographs (Figure 7) considerable grain growth for ferrite and the presence of pearlite formation at the edges with the decrease of hardness. Consequently, the microstructure with large grains size favored the increase on the hydrogen flow through 
TABLE 8: $D^{\text {eff }}$ values of hydrogen for different steels obtained by literature.

\begin{tabular}{lccc}
\hline Authors & $\begin{array}{c}\text { Samples } \\
\text { (steel) }\end{array}$ & Effective diffusion coefficient $\left(D^{\mathrm{eff}}\right)$ \\
& & $\begin{array}{c}\left(\times 10^{-4} \mathrm{~mm}^{2} \cdot \mathrm{s}^{-1}\right) \\
\text { Breakthrough }\end{array}$ \\
\hline Haq et al., 2013 [20] & API X70 (inner) & 2.250 & 3.020 \\
Cheng, 2007 [22] & API X70 (edge) & 1.970 & 2.290 \\
Turnbull and Carroll, 1990 & API X65 & 0.924 & 1.060 \\
[23] & AISI 410 & 0.076 & 0.042 \\
\hline
\end{tabular}

the metal. The annealed microstructure (Figure 7) had lower discordances density than other samples. Therefore, according to Haq et al. [20], ferrite grains often show the highest diffusivity. At the grain boundaries, the pearlite does not act as a blocking to the flux. The lamellar interface of cementite and ferrite within pearlite creates an easy path for hydrogen pass through. In addition, Svoboda et al. [39] confirmed that annealing thermal treatment was enough to recover the majority of defects, decreasing the discordance density, with only a small amount of them remaining. Thereby, the hydrogen atom could easily pass through the metal, the fact that was also confirmed by Han et al. [6].

The diffusivity of hydrogen in pure $\alpha$-iron (ferrite) is around $10^{-3} \mathrm{~mm}^{2} \cdot \mathrm{s}^{-1}$. The value obtained for ABM samples (Table 6) $\left(2.28 \times 10^{-4} \mathrm{~mm}^{2} \cdot \mathrm{s}^{-1}\right)$ is lower due to the presence of pearlite and inclusions. In addition, it is close to those found by Park et al. [2] $\left(9.27 \times 10^{-4} \mathrm{~mm}^{2} \cdot \mathrm{s}^{-1}\right)$ that used similar composition. The slight difference of values can be explained by the difference between the parameters used in both researches; the sample thickness and the current density applied on the cathodic side were different.

3.4.2. Base Metal (BM). Base metal was tested as received, showing micrographs with similar microstructure to ABM, being mainly ferrite grains with pearlite formation at the edges. However, there is a grain size difference. Therefore, it is not possible to affirm what heat treatment the BM was submitted to during its production; however BM presented smaller grain size than ABM, which was submitted to a heat treatment at the laboratory.

The smaller grain size in relation to ABM causes an increase in the number of discordances and defects, raising the hydrogen trapping density and decreasing the diffusion coefficient (Table 6). It was also observed by Haq et al. [20].

$\mathrm{BM}$ had the second highest hydrogen diffusion, below only the $A B M$ and above the other samples. These results are in accordance with Luu and $\mathrm{Wu}$ [40], where the authors compared the diffusion coefficient of different microstructures and concluded that regular ferrite shows the highest values. Han et al. [6] found similar results and concluded that equiaxed ferrite grains and pearlite, as presented in BM, favor the diffusivity of hydrogen due to the low trap density compared with other microstructures.

Comparing Figures 3 and 10(a), BM presented small grain sizes than ABM. According to Haq et al. [20] ferrite grain sizes smaller than $45 \mu \mathrm{m}$ can reduce the mobility of hydrogen by trapping at nodes and triple junctions. Then, finer grains could increase the trapping of hydrogen and thereby give rise to a lower diffusion coefficient.

3.4.3. Quenched Base Metal (QBM). The tests conducted on the QBM (Figure 13 and Table 6) showed lower current flow and enhancement of the time to reach a stationary value to hydrogen permeation than the ABM and BM. Similar results were obtained by Nagu et al. [37] where the quenched material had martensitic interlath interfaces with a bodycentered tetragonal (BCT) matrix, small grains, a large extension of grains boundaries, high density of dislocations, and carbide/matrix interfaces. Therefore, all these characteristics acted as hydrogen traps. The grain boundaries reduce the mobility of hydrogen, acting as reversible hydrogen trapping sites at nodes and junction points [20].

The traps of QBM samples were effective in delaying the hydrogen transport compared with the ABM and BM samples. The fastest cooling rate during heat treatment process promoted the phase transformation to martensite at lower temperature with an increase in dislocations density, arising from the transformation volume change (Figures 10(a) and 10(b)). Then, this behavior is probably due to the difference in grain size caused by thermal treatments performed and generated several changes in the structure of the material.

Considering the dislocations acting as traps for hydrogen, the combined effect of a lower grain size and higher dislocation density could result in the strong trapping hydrogen. It is known that the quenched samples have martensitic microstructure, which owns an atomic arrangement in bodycentered tetragonal (BCT) matrix. Thereby, stable phases at room temperature (ferrite and cementite) cannot be formed due to the fast cooling, differently from the annealed samples $(\mathrm{ABM})$ and the base metal $(\mathrm{BM})$ that present a mixture of ferrite/cementite (pearlite) and grains of ferrite bodycentered cubic system (BCC) [20].

The results are in accordance with literature, where Luu and $\mathrm{Wu}[40]$ also showed that lower permeation and diffusivity of hydrogen occur in martensitic microstructure due to high density of defects and discontinuities imposed by fast cooling. Plus, there is the fact that the matrix is saturated with carbon that does not completely diffuse. Therefore, these combinations of factors act as strong traps and significantly decrease the hydrogen flow. The diffusion coefficient of martensite reported by Olden et al. [41] for API steel X70 is $1.26 \times 10^{-5} \mathrm{~mm}^{2} \cdot \mathrm{s}^{-1}$ and it is lower than those 
found to ferrite/perlite, $7.60 \times 10^{-5} \mathrm{~mm}^{2} \cdot \mathrm{s}^{-1}$. These values are in accordance with this present project; however it shows one order of magnitude lower. It could be explained by the higher level of micro-allowing elements than those present on API X52 steel, which might form precipitations that act as strong traps. Luppo and Ovejero-Garcia [42] also reported similar results, affirming that the hydrogen diffusivity attains a minimum value in a fresh martensite because of the high density of lattice imperfections introduced by martensitic structure. Thus, it is confirmed that the martensitic transformation acts as traps for diffusing hydrogen atoms and consequently a decrease in diffusivity and hydrogen permeation flux.

Svoboda et al. [39] reported that the main factor affecting hydrogen permeation is the hardness, if compared with microstructure or chemical composition. There is a general trend of decreasing the diffusion coefficient with the increasing of strength. However, it is important to note that heat treatment does not change the distribution and chemical composition of the inclusions inside the bulk. Then, the grain boundaries, dislocations, and inclusions can act not only as hydrogen traps, but also as obstacles to physical diffusion through the metal [43].

3.4.4. Weld Metal (WM). The WM samples showed the lowest permeation rate of all analyzed samples (see Table 6 and Figure 13). Due to melting and the solidification process during the welding, WM microstructure was changed. Therefore, the recrystallization and uncontrolled grain growth at the heat-affected zone (HAZ), caused by thermal cycles, increase the density of discordance. In addition, these processes contribute for any factors such as large changes in the microstructure due to the spot heat incidence, phase additions, phase changes, precipitation, residual stresses, discontinuities in the matrix, and many others according to Han et al. [6]. According to Fallahmohammadi et al. [43], hydrogen diffusion decreases when the grains size decreases. Analyzing Figures 2 and 13, WM had small size of grains compared to the other microstructures, causing less hydrogen permeation rate. In addition, during the welding process, the weld metal microstructure is charged because of melting and solidification. The process of recrystallization and grain growth occur differently at the heat-affected zone (HAZ). Then, the welded joints can be affected by different welding heat input and hence to change the hydrogen permeation behavior through the weld metal.

The results imply that an increase seen in the number of discordances was one of the main factors for decay of the diffusion coefficient (Table 6), as seen by $[20,34]$. Moreover, the presence of inclusions had an important role to hold the hydrogen. Variations of microstructure and a significant presence of inclusions are showed in the metallographic analysis of WM in HAZ, Figure 9. Haq et al. [20] reported that a high level of $\mathrm{S}$ and $\mathrm{Mn}$ on the metal may form MnS precipitates, which is a strong reversible trap. They also considered that trapping sites increased with $S$ content. Table 3 shows S content, in WM, as higher than in BM; hence the number of trapping sites is higher as well. It is associated with the low diffusion coefficient presented by WM.
The pearlitic phase is the dominant trap site of diffused hydrogen [2]. These are located at the interface between ferrite and cementite, in lamellar pearlite or the pearlite boundary. Thus, the large number of interfaces of fine cementite in a bainitic structure, as the grains shown in Figure 7(c), acts as a strong inhibitor for hydrogen diffusion. The M/A constituents are expected to be a reversible trap; however the retained austenite does not trap hydrogen significantly alone. Park et al. [2] attribute the great capacity to decrease the diffusion to the interfaces between retained austenite and martensitic layer within $\mathrm{M} / \mathrm{A}$.

\section{Conclusions}

After the experiments, current density was not affected by the changes in microstructure provided by thermal treatments. This could imply that thermal treatments possibly do not affect the corrosion resistance. The low permeation and diffusivity of hydrogen occurred in martensitic microstructure and were related to the high density of defects and discontinuities imposed by rapid cooling. In addition, there is the fact that the matrix is saturated with carbon that does not completely diffuse. Therefore, these combinations of factors act as traps and significantly decrease the hydrogen flow. Plus, the quenched material had martensitic interlath interfaces, high density of dislocations, and carbide-matrix interfaces; all of these act as hydrogen traps. WM samples showed the lowest permeation rate of all analyzed samples as can be seen on the diffusion coefficient calculation. It probably occurred because of melting and solidification process during welding; the weld metal microstructure was changed. Therefore, the recrystallization and uncontrolled grain growth in weld metal and in the heat-affected zone (HAZ), caused by thermal cycles, increase the density of discordance. The lowest rate permeation occurred because of a huge number of discordances and inclusions that works to retard the hydrogen diffusion.

\section{Conflicts of Interest}

The authors declare that they have no conflicts of interest.

\section{Acknowledgments}

This research was financially supported by CNPq, CAPES, Faperj, and Fapemig.

\section{References}

[1] L. Lan, X. Kong, Z. Hu, C. Qiu, D. Zhao, and L. Du, "Hydrogen permeation behavior in relation to microstructural evolution of low carbon bainitic steel weldments," Corrosion Science, vol. 112, pp. 180-193, 2016.

[2] G. T. Park, S. U. Koh, H. G. Jung, and K. Y. Kim, "Effect of microstructure on the hydrogen trapping efficiency and hydrogen induced cracking of linepipe steel," Corrosion Science, vol. 50, no. 7, pp. 1865-1871, 2008.

[3] A. H. S. Bueno, B. B. Castro, and J. A. C. Ponciano, "Assessment of stress corrosion cracking and hydrogen embrittlement 
susceptibility of buried pipeline steels," in Environment-Induced Cracking of Materials, vol. 2, pp. 313-322, Elsevier, 2008.

[4] A. Bueno, E. Moreira, and J. Gomes, "Evaluation of stress corrosion cracking and hydrogen embrittlement in an API grade steel," Engineering Failure Analysis, vol. 36, pp. 423-431, 2014.

[5] A.P. Institute, “API 5L Specification for line pipe," Api Spec 5L. Forty Four, 2007.

[6] Y. Han, H. Jing, and L. Xu, "Welding heat input effect on the hydrogen permeation in the X80 steel welded joints," Materials Chemistry and Physics, vol. 132, no. 1, pp. 216-222, 2012.

[7] Y. Murakam, T. Nomoto, and T. Ueda, "Factors influencing the mechanism of superlong fatigue failure in steels," Fatigue \& Fracture of Engineering Materials \& Structures, vol. 22, no. 7, pp. 581-590, 1999.

[8] D. Eliezer, D. G. Chakrapani, C. J. Altstetter, and E. N. Pugh, "The influence of austenite stability on the hydrogen embrittlement and stress- corrosion cracking of stainless steel," Metallurgical Transactions A, vol. 10, no. 7, pp. 935-941, 1979.

[9] R. J. Asaro and W. A. Tiller, "Interface morphology development during stress corrosion cracking: Part I. Via surface diffusion," Metallurgical Transactions, vol. 3, no. 7, pp. 1789-1796, 1972.

[10] A. H. S. Bueno and J. A. C. Ponciano, "Plano de gerenciamento de integridade de dutos contra corros $\pi \mathrm{o}$," Corros $\pi$ o E Prote $\pi$, vol. 223, pp. 23-38, 2008.

[11] R. P. Gangloff and B. P. Somerday, Gaseous Hydrogen Embrittlement of Materials in Energy Technologies, Elsevier, 2012.

[12] A. Bueno, E. Moreira, P. Siqueira, and J. Gomes, "Effect of cathodic potential on hydrogen permeation of API grade steels in modified NS4 solution," Materials Science and Engineering: A, vol. 597, pp. 117-121, 2014.

[13] A. Contreras, A. Albiter, M. Salazar, and R. Pérez, "Slow strain rate corrosion and fracture characteristics of X-52 and X-70 pipeline steels," Materials Science and Engineering: A, vol. 407, no. 1-2, pp. 45-52, 2005.

[14] D. Xu, Y. Li, F. Song, and T. Gu, "Laboratory investigation of microbiologically influenced corrosion of C1018 carbon steel by nitrate reducing bacterium Bacillus licheniformis," Corrosion Science, vol. 77, pp. 385-390, 2013.

[15] H. Venzlaff, D. Enning, J. Srinivasan et al., "Accelerated cathodic reaction in microbial corrosion of iron due to direct electron uptake by sulfate-reducing bacteria," Corrosion Science, vol. 66, pp. 88-96, 2013.

[16] D. Xu and T. Gu, "Bioenergetics Explains When and Why More Severe MIC Pitting by SRB Can Occur in," in Proceedings of the Corros. NACE International, p. 21, Houston, Tex, USA, 2011.

[17] H. H. Horowitz, "Chemical studies of polythionic acid stresscorrosion cracking," Corrosion Science, vol. 23, no. 4, pp. 353362, 1983.

[18] M. Pourbaix and J. Burbank, "Atlas D-equilibres electrochimiques," Journal of The Electrochemical Society, vol. 111, no. 1, article 14C, 1964.

[19] D. Hardie, E. Charles, and A. Lopez, "Hydrogen embrittlement of high strength pipeline steels," Corrosion Science, vol. 48, no. 12, pp. 4378-4385, 2006.

[20] A. J. Haq, K. Muzaka, D. Dunne, A. Calka, and E. Pereloma, "Effect of microstructure and composition on hydrogen permeation in X70 pipeline steels," International Journal of Hydrogen Energy, vol. 38, no. 5, pp. 2544-2556, 2013.

[21] F. Fischer, G. Mori, and J. Svoboda, "Modelling the influence of trapping on hydrogen permeation in metals," Corrosion Science, vol. 76, pp. 382-389, 2013.
[22] Y. Cheng, "Analysis of electrochemical hydrogen permeation through X-65 pipeline steel and its implications on pipeline stress corrosion cracking," International Journal of Hydrogen Energy, vol. 32, no. 9, pp. 1269-1276, 2007.

[23] A. Turnbull and M. Carroll, "The effect of temperature and $\mathrm{H} 2 \mathrm{~S}$ concentration on hydrogen diffusion and trapping in a $13 \%$ chromium martensitic stainless steel in acidified $\mathrm{NaCl}$," Corrosion Science, vol. 30, no. 6-7, pp. 667-679, 1990.

[24] I. D. Bott, A. F. Ballesteros, and J. A. Ponciano, "Susceptibilidade de juntas soldadas circunferenciais de aço api 51 x80 à corrosão sob tensão e à fragilização por hidrogênio," Tecnologia em Metalurgia e Materiais, vol. 6, no. 3, pp. 147-152, 2010.

[25] R. N. Parkins, W. K. Blanchard, and B. S. Delanty, "Transgranular stress corrosion cracking of high-pressure pipelines in contact with solutions of near neutral pH," Corrosion, vol. 50, no. 5, pp. 394-408, 1994.

[26] J. Capelle, J. Gilgert, I. Dmytrakh, and G. Pluvinage, “The effect of hydrogen concentration on fracture of pipeline steels in presence of a notch," Engineering Fracture Mechanics, vol. 78, no. 2, pp. 364-373, 2011.

[27] T. Gu, "New understandings of biocorrosion mechanisms and their classifications," Journal of Microbial \& Biochemical Technology, vol. 4, no. 4, 2012.

[28] F. Huang, J. Liu, Z. Deng, J. Cheng, Z. Lu, and X. Li, "Effect of microstructure and inclusions on hydrogen induced cracking susceptibility and hydrogen trapping efficiency of X120 pipeline steel," Materials Science and Engineering: A, vol. 527, no. 26, pp. 6997-7001, 2010.

[29] A. Turnbull, "Hydrogen diffusion and trapping in metals," in Gaseous Hydrogen Embrittlement of Materials in Energy Technologies, pp. 89-128, Elsevier, 2012.

[30] B. Vargas-Arista, J. Hallen, and A. Albiter, "Effect of artificial aging on the microstructure of weldment on API 5L X-52 steel pipe," Materials Characterization, vol. 58, no. 8-9, pp. 721-729, 2007.

[31] E. Chatzidouros, V. Papazoglou, and D. Pantelis, "Hydrogen effect on a low carbon ferritic-bainitic pipeline steel," International Journal of Hydrogen Energy, vol. 39, no. 32, pp. 1849818505, 2014.

[32] N. Nanninga, Y. Levy, E. Drexler, R. Condon, A. Stevenson, and A. Slifka, "Comparison of hydrogen embrittlement in three pipeline steels in high pressure gaseous hydrogen environments," Corrosion Science, vol. 59, pp. 1-9, 2012.

[33] A. H. S. Bueno, Avaliação integrada de mecanismos de falha por corrosão em dutos, Universidade Federal do Rio de Janeiro, 2007.

[34] A. H. Bueno and J. A. Gomes, "Environmentally induced cracking of API grade steel in near-neutral pH soil," Journal of the Brazilian Society of Mechanical Sciences and Engineering, vol. 31, no. 2, pp. 97-104, 2009.

[35] A. B. Forero, J. A. Ponciano, and I. S. Bott, "Susceptibility of pipeline girth welds to hydrogen embrittlement and sulphide stress cracking," Materials and Corrosion, vol. 65, no. 5, pp. 531541, 2014.

[36] M. M. Hall, "Effect of inelastic strain on hydrogen-assisted fracture of metals," in Gaseous Hydrogen Embrittlement of Materials in Energy Technologies, pp. 378-429, 2012.

[37] G. A. Nagu, Amarnath, and T. K. Namboodhiri, "Effect of heat treatments on the hydrogen embrittlement susceptibility of API X-65 grade line-pipe steel," Bulletin of Materials Science, vol. 26, no. 4, pp. 435-439, 2003. 
[38] V. Ramunni, T. D. Coelho, and P. de Miranda, "Interaction of hydrogen with the microstructure of low-carbon steel," Materials Science and Engineering: A, vol. 435-436, pp. 504-514, 2006.

[39] J. Svoboda, G. Mori, A. Prethaler, and F. Fischer, "Determination of trapping parameters and the chemical diffusion coefficient from hydrogen permeation experiments," Corrosion Science, vol. 82, pp. 93-100, 2014.

[40] W. Luu and J. Wu, "The influence of microstructure on hydrogen transport in carbon steels," Corrosion Science, vol. 38, no. 2, pp. 239-245, 1996.

[41] V. Olden, A. Alvaro, and O. M. Akselsen, "Hydrogen diffusion and hydrogen influenced critical stress intensity in an API X70 pipeline steel welded joint - Experiments and FE simulations," International Journal of Hydrogen Energy, vol. 37, no. 15, pp. 11474-11486, 2012.

[42] M. Luppo and J. Ovejero-Garcia, "The influence of microstructure on the trapping and diffusion of hydrogen in a low carbon steel," Corrosion Science, vol. 32, no. 10, pp. 1125-1136, 1991.

[43] E. Fallahmohammadi, F. Bolzoni, G. Fumagalli, G. Re, G. Benassi, and L. Lazzari, "Hydrogen diffusion into three metallurgical microstructures of a C-Mn X65 and low alloy F22 sour service steel pipelines," International Journal of Hydrogen Energy, vol. 39, no. 25, pp. 13300-13313, 2014. 

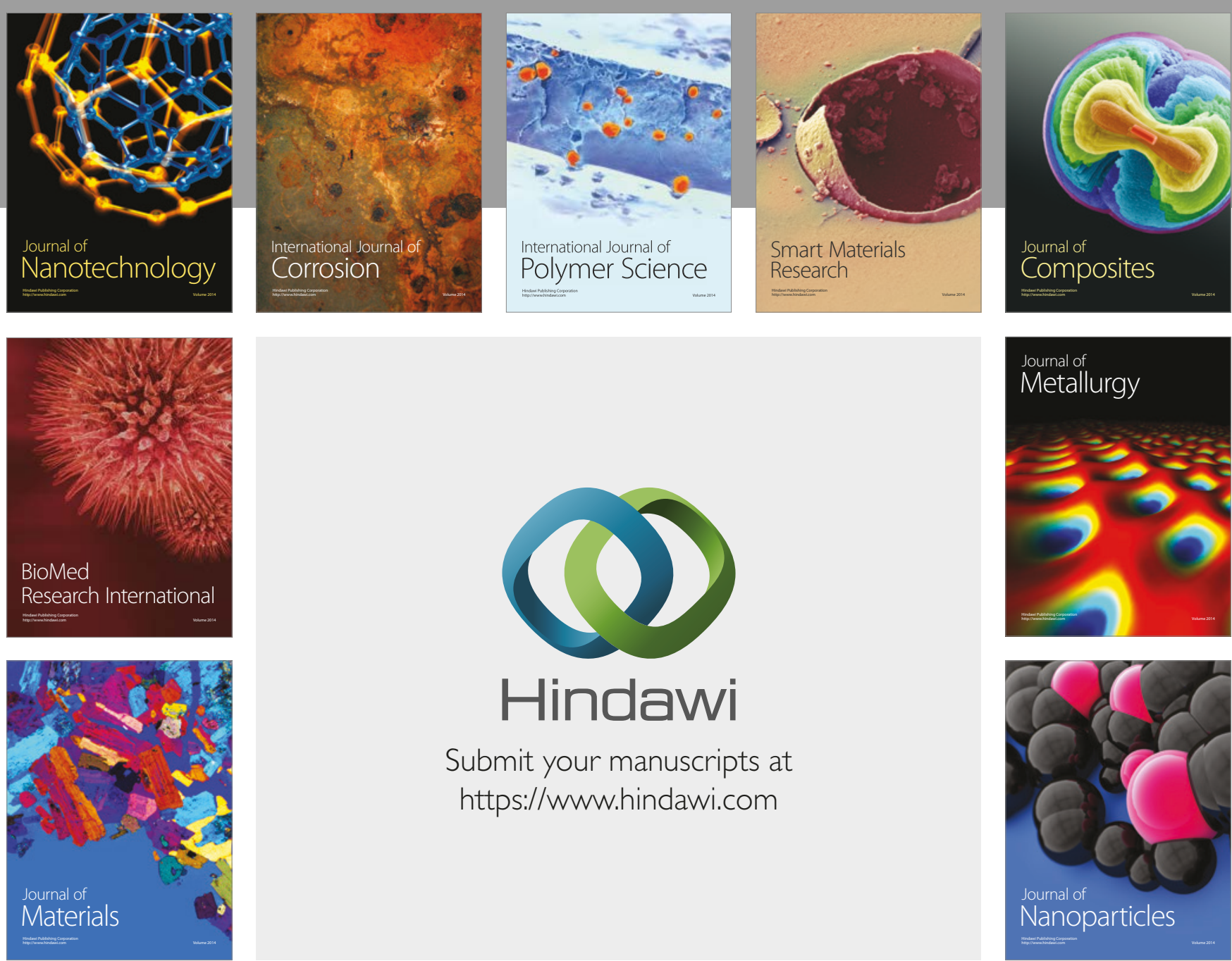

\section{Hindawi}

Submit your manuscripts at

https://www.hindawi.com
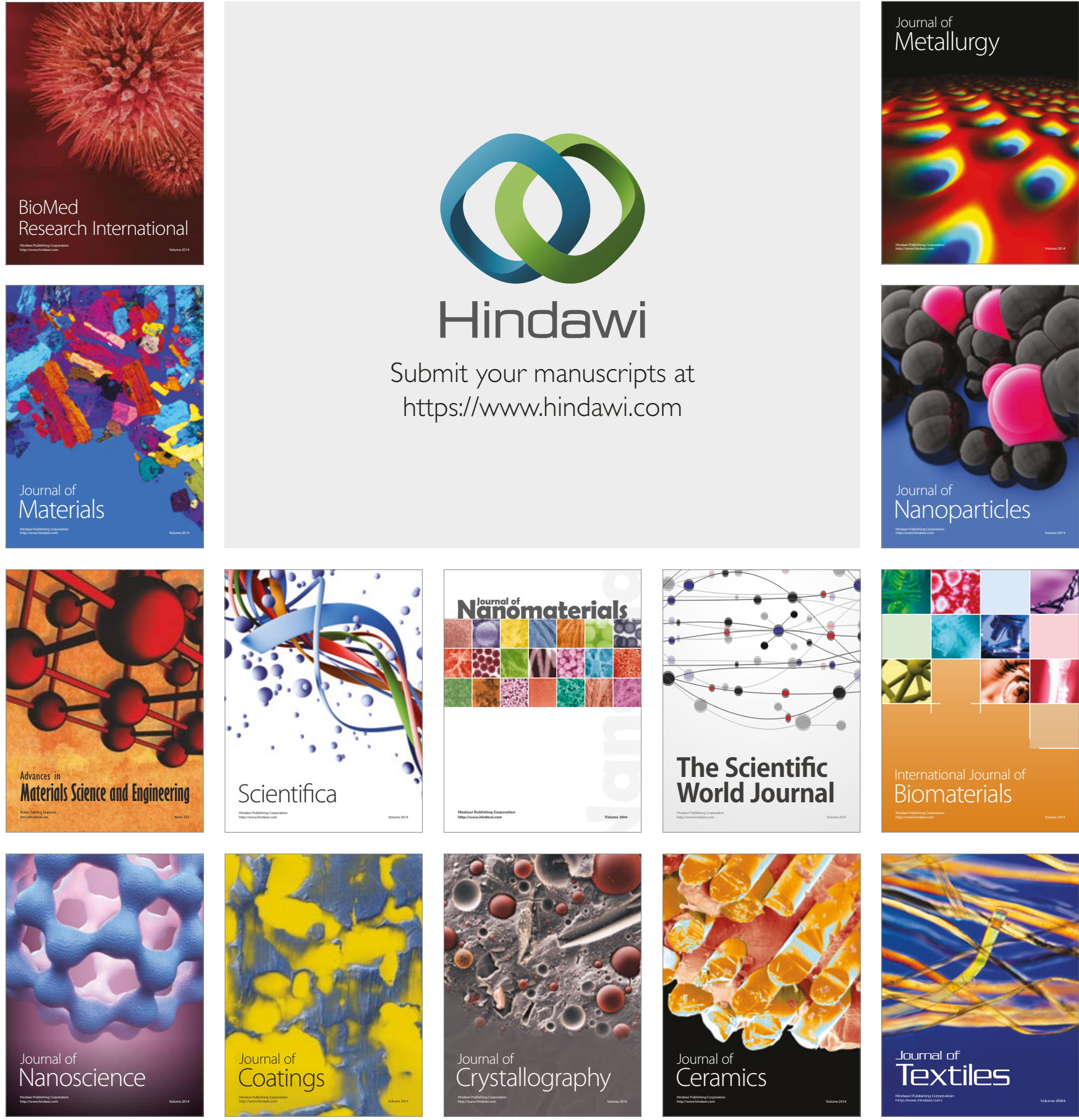

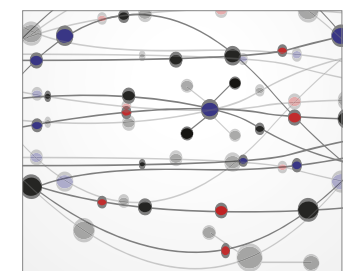

The Scientific World Journal
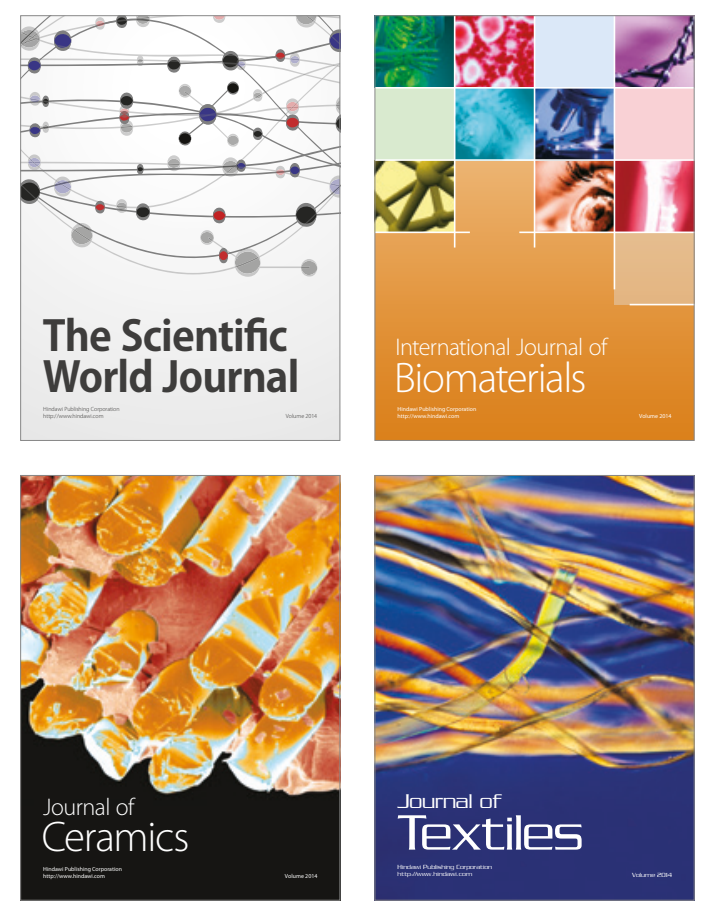